\title{
INFLUENCE OF THE LAURACEAE FAMILY ON THE DYNAMICS OF A MIXED OMBROPHILOUS FOREST REMNANT
}

\author{
Wesllen Schuhli Kieras ${ }^{1}$, Sebastião do Amaral Machado², Allan Libanio Pelissari², Vinicius Costa Cysneiros ${ }^{3}$, \\ Samuel Alves da Silva ${ }^{3 *}$ \\ ${ }^{1}$ Juliana Florestal LTDA, Forest Analyst, Caçador, Santa Catarina, Brazil - wesllenkieras@ gmail.com ; \\ ${ }^{2}$ Federal University of Paraná, Department of Forest Sciences, Curitiba, Paraná, Brazil - samachado@ufpr.br, allanpelissari@gmail.com ; \\ ${ }^{3 *}$ Federal University of Paraná, CNPq Scholarship Holder, Graduate Program in Forest Engineering, Curitiba, Paraná, Brazil - \\ vccysneiros.florestal@gmail.com, ssilva.alves@yahoo.com.br*
}

Received for publication: 27/06/2019 - Accepted for publication: 18/09/2020

\begin{abstract}
Resumo
Influência da família Lauraceae na dinâmica de um remanescente de Floresta Ombrófila Mista. A família Lauraceae apresenta um dos maiores valores de importância na Floresta Ombrófila Mista (FOM). O valor comercial de algumas de suas espécies foi motivo de intensa exploração florestal na região Sul do Brasil. Considerando a hipótese de que ela exerce subsídio essencial para constituição dessa tipologia florestal, o objetivo deste trabalho foi identificar e quantificar a influência da família Lauraceae na dinâmica de um remanescente de FOM de 15,2 ha. Os dados censitários foram coletados a cada três anos, desde 2007, onde todos os indivíduos com circunferência a $1,3 \mathrm{~m}$ igual ou superior a $30 \mathrm{~cm}$ foram identificados e mensurados. A dinâmica foi analisada por meio do incremento periódico em diâmetro, ingresso e mortalidade entre os períodos de medição, enquanto as análises multivariadas de agrupamento e correlação canônica foram aplicadas para a formação de grupos de espécies e quantificação de suas importâncias na dinâmica do remanescente. As prognoses das distribuições diamétricas da família e espécies foram obtidas por meio da matriz de transição. Foram identificadas onze espécies da família Lauraceae, as quais apresentaram distribuição diamétrica decrescente e valor de importância de 9,51\%. Com a análise de agrupamento, foi verificada a formação de cinco grupos, ao passo que a correlação canônica de 0,551 foi considerada moderada e estatisticamente significativa pelo teste Lambda de Wilks. Por meio da projeção da distribuição diamétrica verificou-se que a comunidade é estável e auto-regenerativa. Embora seja considerada moderada, a influência da família sobre o remanescente florestal tende a aumentar com o avanço da sucessão ecológica.

Palavras-chave: Análise de agrupamento; Correlação canônica; Matriz de transição; Sucessão florestal;
\end{abstract} Floresta com Araucária.

\section{Abstract}

Lauraceae family has one of the highest values of importance in the Mixed Ombrophilous Forest (MOF). The commercial value of some of its species was a reason for intense forest exploitation in the southern region of Brazil. Considering the hypothesis that it provides an essential subsidy for the constitution of this forest type, the aim of this study was to identify and quantify the influence of Lauraceae family in the dynamics of a 15.2 ha MOF remnant. Census data were collected every three years, since 2007, in which all trees with a circumference at $1.3 \mathrm{~m}$ height equal to or greater than $30 \mathrm{~cm}$ were identified and measured. Dynamics were analyzed by periodic increment in diameter, recruitment, and mortality through the measurement periods, while cluster multivariate analysis and canonical correlation were applied for grouping species and assessing their importance on the forest remnant dynamics. Diameter distribution prognosis of Lauraceae and its species was obtained through a transition matrix. Eleven tree species of Lauraceae family were identified, which showed decreasing diameter distribution and value of importance equals to $9.51 \%$. Using cluster analysis, five groups were obtained, while the canonical correlation of 0.551 was considered moderate and statistically significant by Wilks' Lambda test. By the projection of diameter distribution, it was verified that the study community is stable and self-regenerative. Although it is considered moderate, the influence of family on the forest remnant tends to increase with the advance of ecological succession.

Keywords: Cluster analysis; Canonical correlation; Transition matrix; Forest succession; Araucaria's forest.

\section{INTRODUCTION}

Mixed Ombrophilous Forest (MOF) is one of the native forest phytophysiognomies under the domain of the Atlantic Forest. Like the whole biome, its vegetation area has been drastically reduced and fragmented (RIBEIRO et al., 2009). Characterized by the dominance of Araucaria angustifolia (Bertol.) Kuntze tree species, the MOF is also known as Araucaria's forest and, although small remnants are found in eastern Paraguay and in the extreme northeast of Argentina, its largest area of occurrence is located in Brazil (REIS et al., 2018).

Irregularly distributed and associated with the country's high-altitude regions, MOF originally covered approximately 200,000 $\mathrm{km}^{2}$ and was mainly concentrated in Paraná (40\%), Santa Catarina (31\%) and Rio Grande do Sul States (25\%). It also occurred in small fragments in São Paulo (3\%), Minas Gerais and Rio de Janeiro

FLORESTA, Curitiba, PR, v. 51, n. 1, p. 164-173, jan/mar 2021.

Kieras, W. S. et.al.

ISSN eletrônico 1982-4688

DOI: $10.5380 /$ rf.v51 i1. 67629 
States (1\%) (KLEIN, 1960; REIS et al., 2018).

According to Ebling et al. (2013), among the great diversity of tree species present in the MOF area, Lauraceae family stands out for its ecological representativeness and timber potential. Higuchi et al. (2012) reports that, due to their woody economic importance, some species of this family were intensively explored during the woody cycle in 1950s and 1960s. Additionally, Fontana et al. (2016) points out that the Lauraceae family plays a fundamental role in the MOF formation, in which some species became exclusive to this vegetation, such as Ocotea porosa (Nees \& Mart.) Barroso and Cinnamomum sellowianum (Nees) Kosterm.

Based on Braun-Blanquet concept of fidelity, species are classified in five degrees; as to know exclusive or faithful, selective, preferential, indifferent, and accidental, Klein (1974) presented the hypothesis that the Lauraceae family provides an essential subsidy for the Araucaria's forest constitution. However, despite being crucial to guide the species management and conservation of Lauraceae family, this hypothesis has not been scientifically proven.

Although it presents ecological importance and economic potential, in general, the studies developed specifically with Lauraceae family are limited to the botanical description. On the other hand, there are countless studies that describe the phytosociological structure of MOF that, indirectly, address the ecological and dynamic aspects related to this family, among which, many report the high importance value of species of Lauraceae family in the structure of MOF fragments. in intermediate and advanced stages of natural regeneration (HERRERA et al., 2009; FIGUEIREDO FILHO et al. 2010; CALLEGARO et al., 2015; CUBAS et al. 2016).

The study of forest dynamics and ecological succession can help for understanding the importance of botanical families in forest communities. Using statistical techniques, some studies were developed with the purpose of contributing to the generation of information on the dynamics of the MOF remnants. Among them, we highlight Figueiredo Filho et al. (2010) and Cubas et al. (2016). Such studies sought to evaluate the structural changes of species over time in the community's processes through growth, mortality, and recruitment, to enable the understanding of the development of species and forest fragments.

Used by Ávila et al. (2011) to describe the presence of floristic clusters in the natural regeneration mechanisms and the influence of environmental factors on the species' distribution in a MOF remnant, multivariate analysis is a tool to assess the relationship of species in forest dynamics. Thus, in order to verify the hypothesis presented by Klein (1974) the aim of this study was to identify and quantify the influence of tree species of Lauraceae family on the dynamics of a MOF remnant.

\section{MATERIAL AND METHODS}

\section{Characterization of the study area}

The study area corresponds to a MOF fragment located in the municipality of Curitiba, Paraná State, Brazil, between the coordinates $25^{\circ} 26^{\prime} 5^{\prime \prime}$ and $25^{\circ} 27^{\prime} 33^{\prime \prime} \mathrm{S}$ and $49^{\circ} 14^{\prime} 16^{\prime \prime}$ and $49^{\circ} 14{ }^{\prime} 33^{\prime \prime} \mathrm{W}$, with an altitude of approximately equal to $930 \mathrm{~m}$. The climate of the region, according to Köppen, is Cfb (subtropical humid mesothermal), with mild summers, winters with frequent frosts and absence of dry season. The annual average temperatures in the hottest months are below $22^{\circ} \mathrm{C}$, while in the coldest months they are below $18^{\circ} \mathrm{C}$, resulting in an average annual temperature of $17^{\circ} \mathrm{C}$ (MACHADO et al., 2008).

The forest fragment area is approximately 15.24 ha, with 12.96 ha occupied by MOF and 2.28 ha by floodplains. This fragment is found in an area with a high anthropization degree, favoring the development of pioneer tree species. The soils present at the site are classified as Hydromorphic in the areas closer to the drainage channels and Cambisols Podzolic in the regions with greater drainage.

The database consisted of 10,405 trees from a census conducted between 2007 and 2016, at three-year intervals. In order to facilitate the access to the trees and georeferencing, the area was divided into $2,500 \mathrm{~m}^{2}(50$ $\mathrm{mx} 50 \mathrm{~m})$ blocks, totaling 70 blocks, each divided into five $500 \mathrm{~m}^{2}(10 \mathrm{mx} 50 \mathrm{~m})$ sub-blocks, Within the subblocks, trees with circumference at breast height at $1.3 \mathrm{~m}$ (c) equals to or greater than $30 \mathrm{~cm}$ were measured and identified.

\section{Horizontal structure and forest dynamics}

The data were submitted to the processing of horizontal structure, using population parameters by species, such as measurements of density (abundance), dominance, frequency, and value of importance. Additionally, after the transformation of $c$ into diameter at breast height $(d)$, the diameter distribution and dynamics were processed, obtaining the number of trees per species in the fragment during the measurement period, basal area by species, periodic (1) and annual (2) increments in $d$, periodic (3) and annual (4) increments in basal area, mortality, and recruitment. The dynamics was also assessed based on the recruitment and mortality rates between occasions in the forest inventory.

$$
P I_{d}=d_{e}-d_{b}
$$

FLORESTA, Curitiba, PR, v. 51, n. 1, p. 164-173, jan/mar 2021.

Kieras, W. S. et.al.

ISSN eletrônico 1982-4688

DOI: $10.5380 /$ rf.v51 i1. 67629 


$$
\begin{gathered}
A P I_{d}=\frac{P I_{d}}{R} \\
P I_{G}=G_{e}-G_{b} \\
A P I_{G}=\frac{P I_{G}}{R}
\end{gathered}
$$

Where: $P I_{d}=$ periodic increment in $d(\mathrm{~cm}) ; A P I_{d}=$ annual periodical increment in $d(\mathrm{~cm} /$ year $) ; d_{e}=d$ at the end of the evaluated growth period $(\mathrm{cm}) ; d_{b}=d$ at the beginning of the evaluated growth period; $P I_{G}=$ periodic increment in basal area $\left(\mathrm{m}^{2} / \mathrm{ha}\right) ; A P I_{G}=$ annual periodical increment in annual basal area $\left(\mathrm{m}^{2} / \mathrm{ha}\right) ; G_{e}=$ basal area at the end of the evaluated period $\left(\mathrm{m}^{2} / \mathrm{ha}\right) ; G_{b}=$ basal area at the beginning of the evaluated period $\left(\mathrm{m}^{2} / \mathrm{ha}\right) ; R=$ measurement range (years).

\section{Species cluster analysis}

The existence of similar groups referring to forest dynamics was verified through the cluster analysis, in which the values of recruitment, mortality and annual periodical increment in $d$ between the measurement periods were transformed into Euclidean distance and grouped by the Ward's method link for the elaboration of a species dendrogram. Ward's method tends to result in clusters of similar dimensions, due to the minimization of internal variation, being the one indicated for the present study (CALLEGARO et al., 2015).

To perform the grouping, the Lauraceae family matrix of variables was structured into type, recruitment, mortality, and annual periodic increase in $d$, which data were related to the measurement period. The number of groups was selected from the maximum value or the one immediately preceding the pseudo- $\mathrm{t}^{2}$ to establish the cutoff point in the similarity dendrogram.

\section{Canonical correlation}

The multivariate canonical correlation analysis was used to verify the correlations between the dynamics of the MOF as a whole and the dynamics of species groups within the Lauraceae family. This approach sought to generate linear combinations of the dependent and independent variables to obtain pairs of correlations between these combinations. In the present study, the dependent variable corresponded to the MOF dynamics, while the independent variables were formed by the dynamics of each tree species group belonging to the Lauraceae family.

Through this analysis, canonical pairs were calculated to determine the weight of the Lauraceae family's influence on the dynamics of the forest remnant. Thus, similar to the interpretation of the coefficients' significance in the regression analysis, with greater canonical weight in a given species group, greater influence on the MOF dynamics is found. Also, the signs on the weights (positive or negative) were considered, as the relationships can be reversed. Additionally, to verify the significance of canonical correlations, Wilks' Lambda multivariate test was used.

\section{Projection of diameter distribution}

A transition matrix is a stochastic process in which it is assumed that, over a period, a given tree, in a given diameter class, from its current dimension, can grow and change to another class, not growing enough to that and stay in the same class, or even die (VANCLAY, 1995).

The transition probability for each measurement interval was obtained by means of the ratio between the number of trees that died, or changed classes, or remained in the same class, by the number of trees in the respective class at the beginning of the evaluation period. Thus, the transition matrix was applied at the family level and for the most frequent Lauraceae species, in which the projected diameter distribution of time $t_{i}$ para $t_{i+1}$ can be determined by the current state and by the entry in the time interval.

Thus, class intervals of $3 \mathrm{~cm}$ were defined to obtain more accurate estimates, as recommended by Ebling et al. (2013). Furthermore, the projection of the forest remnant structure for a period (5) was obtained by multiplying the probability of transition by the number of trees in the current period, added to the number of new or recruited trees.

$$
Y_{t+\Delta t}=G \cdot Y_{i t}+I_{i t}
$$

Where: $Y_{t+\Delta t}=$ vector of the number of projected trees; $G=$ transition probability matrix by class of $d ; Y_{i t}=$ frequency of the class of $d$; $I_{i t}=$ number of new or recruited trees.

The prognosis of diameter distribution was carried out for periods of three years, starting from the inventories of 2010 and 2013. Thus, to assess the quality of the projections, the diameter distribution was projected for the year 2016 and subsequently compared with the observed values. For this, the Kolmorogov-

FLORESTA, Curitiba, PR, v. 51, n. 1, p. 164-173, jan/mar 2021.

Kieras, W. S. et.al.

ISSN eletrônico 1982-4688

DOI: $10.5380 /$ rf.v51 i1. 67629 
Smirnov's (KS) test was used at 5\% probability level, aiming to assess the adherence index, given by the nonsignificance between the observed and projected distributions in 2016.

\section{RESULTS}

\section{Horizontal and diameter structures}

The Lauraceae family obtained the third highest value of importance in the forest remnant, with $9.51 \%$, being lower than the Salicaceae (11.02\%) and Araucariaceae (11.56\%) families. Altogether, 11 tree species of Lauraceae family were identified, which corresponded to 1,022 individuals in 2016. We highlighted Ocotea puberula (Rich.) Nees, which represented $40.4 \%$ of this population, resulting in a density of 28 individuals per hectare, which were found in $91.4 \%$ of the measured area.

The Lauraceae family species showed a decreasing diameter distribution tendency, typical of the structure of uneven-aged and mixed forests, with the existence of a few trees with values of $d$ greater than 60 $\mathrm{cm}$, while the highest frequencies were observed in the first diameter classes. The prognoses of diameter distributions and real values for 2016 for O. puberula, Ocotea nutans (Ness.) Mez, Nectandra lanceolata Ness., and Ocotea bicolor Vattimo species were evaluated (Figure 1). Due to the low frequency of individuals, it was not possible to evaluate the distribution of other species.

a) O. puberula

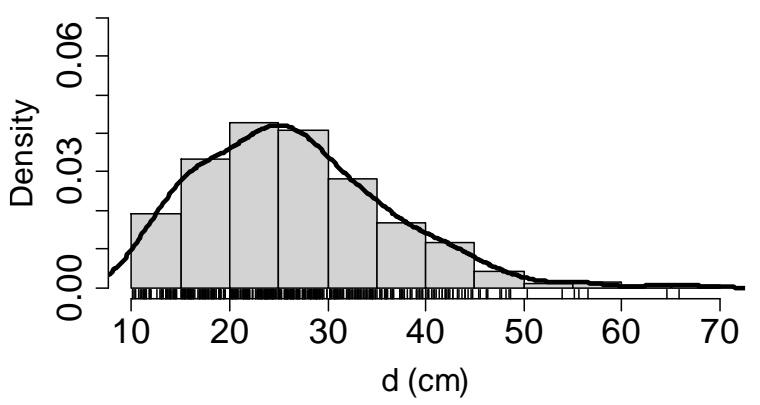

c) N. lanceolata

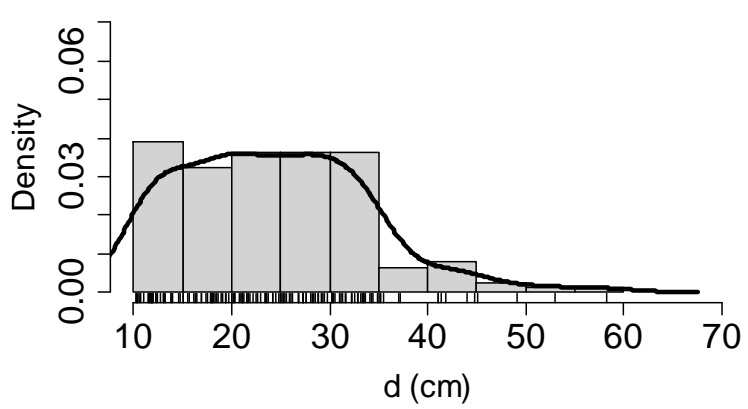

b) O. nutans

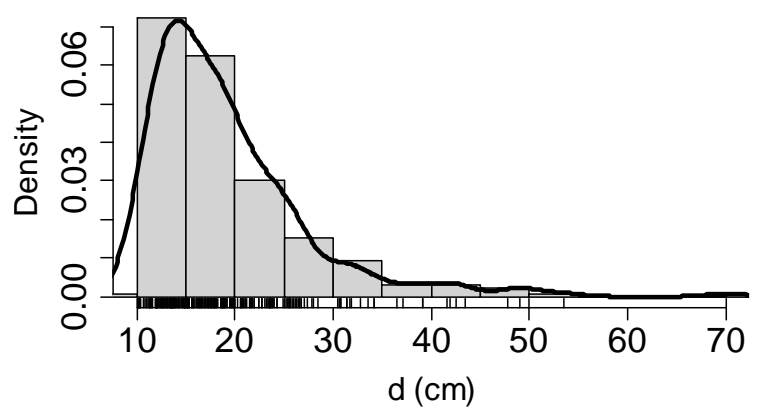

d) O. bicolor

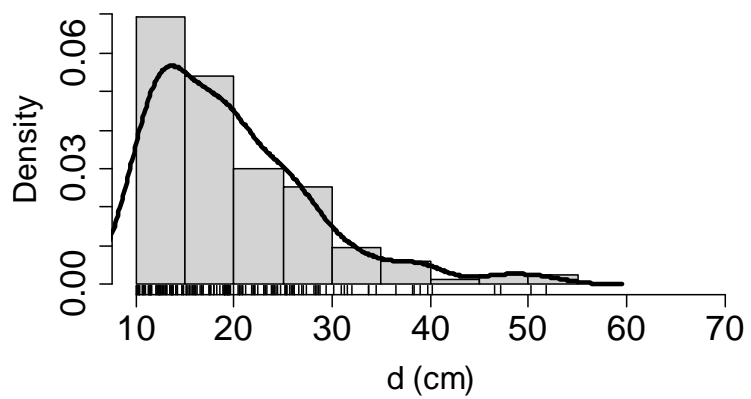

Figura 1. Distribuição diamétrica das espécies de maior frequência da família Lauraceae no remanescente de Floresta Ombrófila Mista no ano de 2016. Onde o histograma representa os valores reais observados e, a curva representa a prognose baseada nos anos anteriores.

Figure 1. Diameter distribution of the most frequent species of Lauraceae family in a Mixed Ombrophilous Forest remnant. Where the histogram represents the actual observed values, and the curve represents the prognosis based on previous years.

As it can be seen by the higher frequency of trees in the first diameter classes, O. nutans (Figure 1b) and $O$. bicolor (Figure 1d) species showed distribution with decreasing behavior and high rate of recruited trees. On the other hand, $O$. puberula species (Figure 1a) presented diameter distribution with unimodal tendency, with strong positive asymmetry. Finally, N. lanceolata (Figure 1c) species showed distribution with symmetric characteristics, in which the diameter classes showed similar frequencies.

\section{Population dynamics}

The community of Lauraceae family increased $5.86 \%$ between evaluation period (2007 - 2016), with emphasis to $O$. nutans species, with an increase in the population in relation to the first measurement. While $O$.

FLORESTA, Curitiba, PR, v. 51, n. 1, p. 164-173, jan/mar 2021.

Kieras, W. S. et.al.

ISSN eletrônico 1982-4688

DOI: 10.5380/rf.v51 i1. 67629 
puberula presented higher mortality, resulting in decrease in this species population. During this period, different characteristics were observed in the rates of recruitment and mortality among the species of this family (Table $1)$.

Additionally, C. sellowianum presented the largest annual periodic increase in $d$, however, it is noteworthy that only one tree was observed in the forest fragment. In relation to the basal area, Lauraceae family showed a considerable increase in basal area between measurements, increasing from $36.25 \mathrm{~m}^{2}\left(2.38 \mathrm{~m}^{2} \mathrm{ha}^{-1}\right)$ in 2007 to $51.02 \mathrm{~m}^{2}\left(3.35 \mathrm{~m}^{2} \mathrm{ha}^{-1}\right)$ in 2016 .

Tabela 1. Dinâmica das espécies da família Lauraceae entre 2007 e 2016 no remanescente de Floresta Ombrófila Mista.

Table 1. Species dynamics of Lauraceae family between 2007 and 2016 in a Mixed Ombrophilous Forest remnant.

\begin{tabular}{|c|c|c|c|c|c|}
\hline Species & $\mathrm{N} 1$ & $\mathrm{~N} 2$ & $\mathrm{R}$ & $\mathrm{M}$ & $\mathrm{I}$ \\
\hline Ocotea puberula (Rich.) Nees & 433 & 413 & 2.4 & 4.4 & 0.419 \\
\hline Ocotea nutans (Nees) Mez & 218 & 258 & 4.5 & 0.4 & 0.374 \\
\hline Nectandra lanceolata Nees & 130 & 141 & 1.9 & 0.8 & 0.556 \\
\hline Ocotea bicolor Vattimo & 142 & 158 & 2.6 & 1 & 0.383 \\
\hline Nectandra megapotamica (Spreng.) Nees & 12 & 24 & 1.3 & 0.3 & 0.461 \\
\hline Cryptocarya aschersoniana $\mathrm{Mez}$ & 11 & 11 & 0.2 & 0.2 & 0.592 \\
\hline Cinnamomum vesiculosum (Ness) Kosterm. & 7 & 8 & 0.1 & 0.2 & 0.458 \\
\hline Ocotea pulchella (Nees) Mez & 4 & 6 & 0.4 & 0.2 & 0.384 \\
\hline Cinnamomum glaziovii (Ness) Kosterm. & 1 & 2 & 0.1 & 0 & 0.261 \\
\hline Cinnamomum sellowianum (Nees at Mart) Kosterm. & 1 & 1 & 0 & 0 & 1.216 \\
\hline Cinnamomum amoenum (Ness) Kosterm. & 1 & 1 & 0 & 0 & 0.153 \\
\hline
\end{tabular}

$\mathrm{N} 1=$ number of trees in $2007 ; \mathrm{N} 2=$ number of trees in $2016 ; \mathrm{R}=$ annual recruitment rate $(\%) ; \mathrm{M}=$ annual mortality rate $(\%)$; and $\mathrm{I}=$ annual periodic increment in $d(\mathrm{~cm})$.

\section{Species grouping}

Through cluster analysis, five groups of species were defined, which differed in relation to the dynamics (Figure 2): Group 1: C. amoenum and C. glaziovii; Group 2: C. aschersoniana, C. vesiculosum and O. pulchella; Group 3: N. lanceolata, N. megapotamica and O. bicolor; Group 4: O. nutans; and Group 5: O. puberula. On the other hand, $C$. sellowianum species was removed from the analysis due to presented only one tree, resulting in the lack of variability.

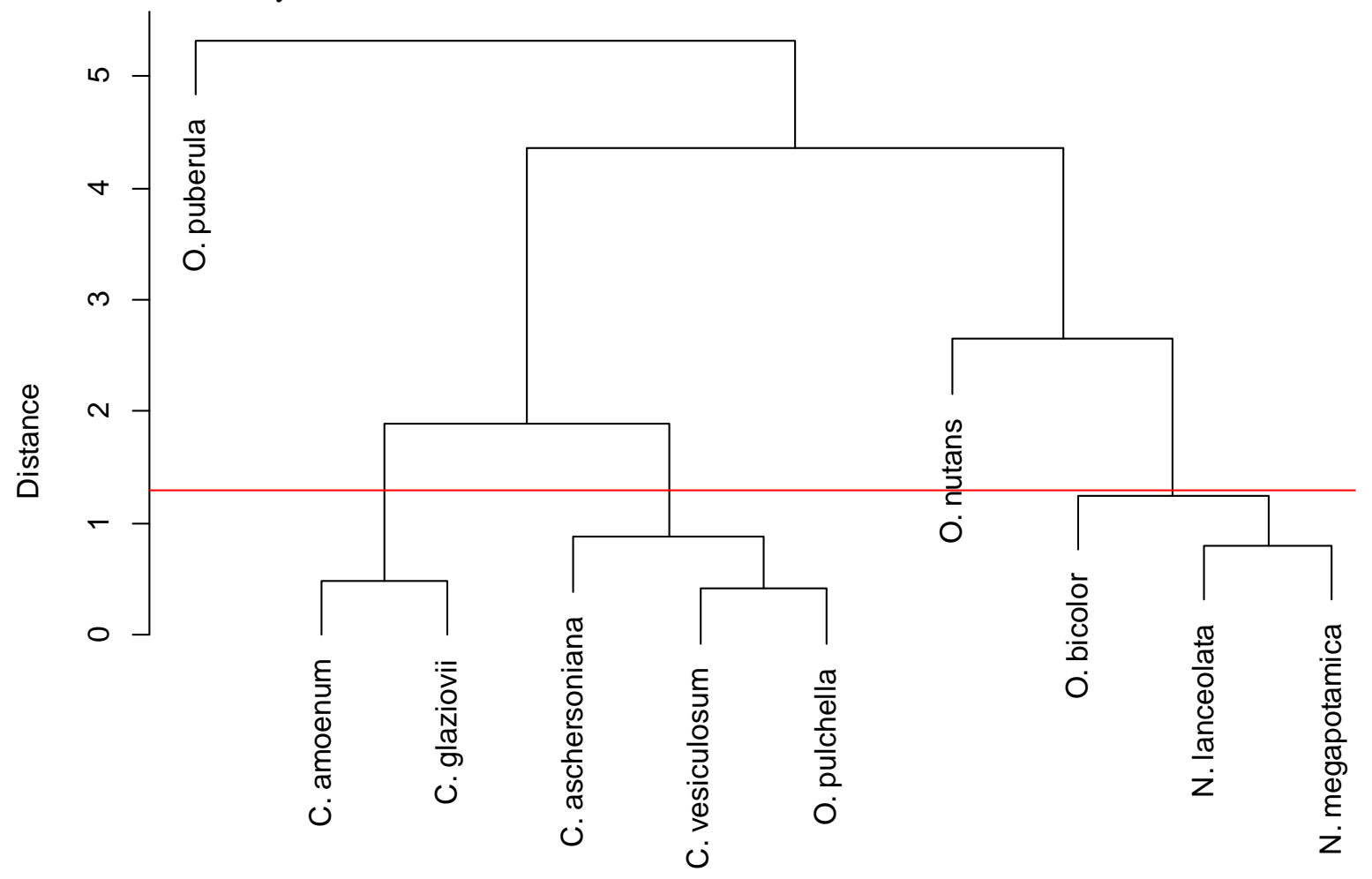

FLORESTA, Curitiba, PR, v. 51, n. 1, p. 164-173, jan/mar 2021.

Kieras, W. S. et.al. 
Figura 2. Dendrograma de similaridade dos grupos de espécies da família Lauraceae no remanescente de Floresta Ombrófila Mista.

Figure 2. Similarity dendrogram of species Lauraceae family groups in a Mixed Ombrophilous Forest remnant.

\section{Canonical correlation}

After the formation of Lauraceae species groups, the canonical correlation observed was 0.551, with statistical significance by the Wilks' Lambda test ( $p$-value $<0.0001$ ), indicating that the Lauraceae family dynamics moderately explained the dynamics of MOF remaining. The weights of correlations between recruitment, mortality, and annual periodical increment in $d$ of respective Lauraceae groups in relation to the fragment dynamics are described in Table 2.

Tabela 2. Pesos canônicos entre as dinâmicas dos grupos de espécies da família Lauraceae e do remanescente de Floresta Ombrófila Mista.

Table 2. Canonical weights between the dynamics of species groups of Lauraceae family and Mixed Ombrophilous Forest remnant.

\begin{tabular}{cccc}
\hline Group & Recruitment & Mortality & Increment \\
\hline 1 & -0.048 & 0.000 & 0.135 \\
2 & 0.085 & 0.022 & 0.108 \\
3 & 0.075 & 0.252 & 0.273 \\
4 & 0.007 & 0.095 & 0.208 \\
5 & -0.011 & 0.381 & -0.059 \\
\hline
\end{tabular}

The highest canonical correlation for the variable increment was obtained in Group 3, showing its greatest influence on the dynamics. For recruitment, Group 2 had the highest values, however, the canonical weights for this variable were considered low, indicating that the overall recruitment rate differs from the Lauraceae family. On the other hand, Group 5 had the highest canonical weight for mortality, revealing that $O$. puberula species showed the greatest influence on the forest remnant mortality.

\section{Diameter distribution prognosis}

The first projection of diameter distribution was made for 2016, based on the observations of 2010 and 2013. Thus, through the Kolmogorov-Smirnov's (KS) test, it was observed that the distributions were statistically adherent, with an estimated KS of 0.021 and critical value equal to 0.051. Subsequently, projections were made for 2019 and 2022 (Figure 3).

a) Diameter distribuition in $\mathbf{2 0 1 6}$

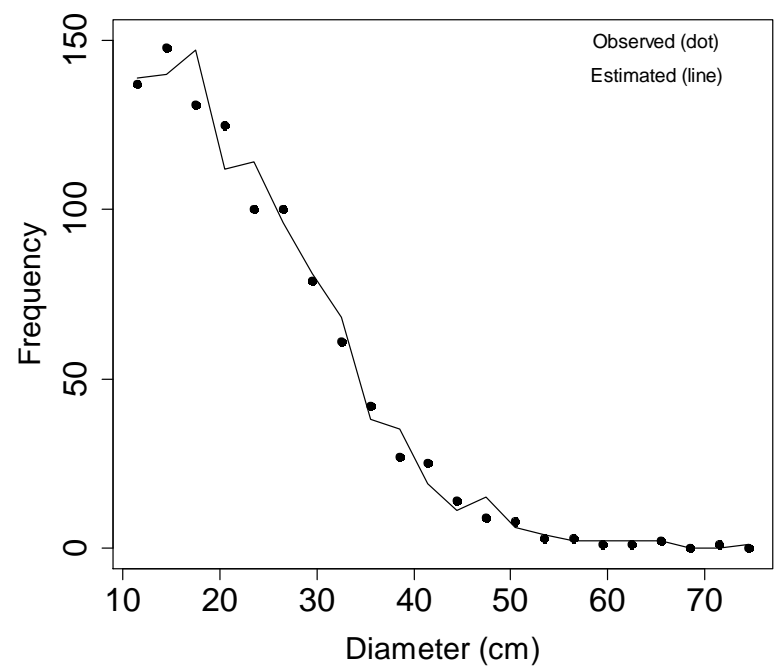

b) Prognoses of diameter distribution

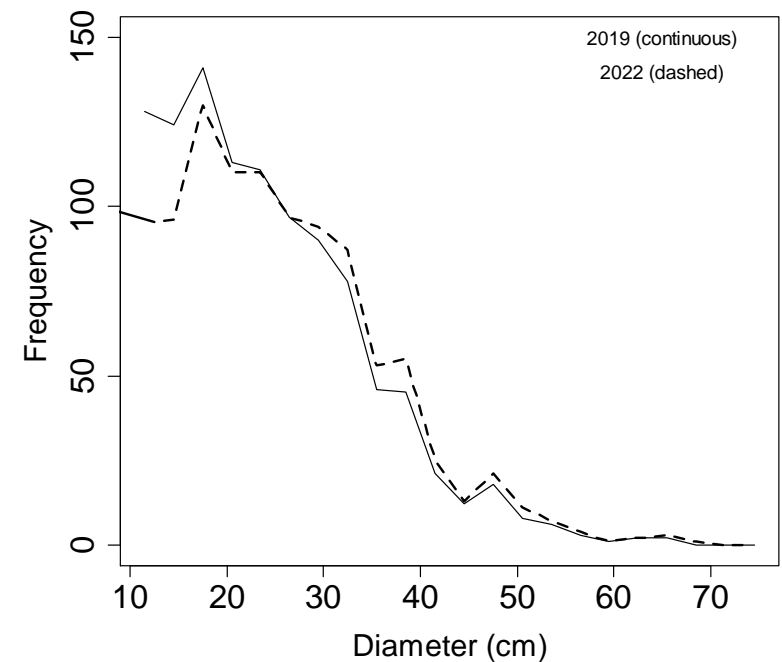

Figura 3. Distribuições diamétricas observada e estimada dos indivíduos da família Lauraceae em 2016 (a) e prognoses para 2019 e 2022 (b) para o remanescente de Floresta Ombrófila Mista.

Figure 3. Observed and estimated tree diameter distributions of Lauraceae family in 2016 (a) and prognoses for 2019 and 2022 (b) for the Mixed Ombrophilous Forest remnant.

Additionally, the transition matrices for $O$. nutans, $N$. lanceolata and $N$. bicolor species were modeled and diameter distributions were projected for 2019 and 2022 (Figure 4). It was found that $O$. nutans showed a

FLORESTA, Curitiba, PR, v. 51, n. 1, p. 164-173, jan/mar 2021.

Kieras, W. S. et.al.

ISSN eletrônico 1982-4688

DOI: $10.5380 /$ rf.v51 i1. 67629 
high number of trees' recruitment throughout the measurement periods, in which that the projections showed an increase of $4.65 \%$ in the population for 2022, when compared to 2016.

a) O. nutans

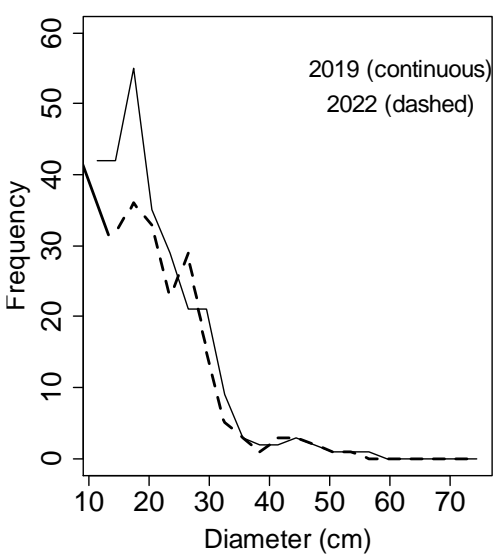

b) N. lanceolata

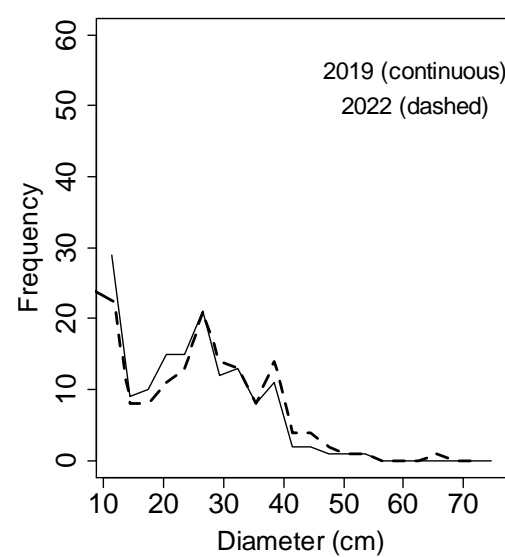

c) O. bicolor

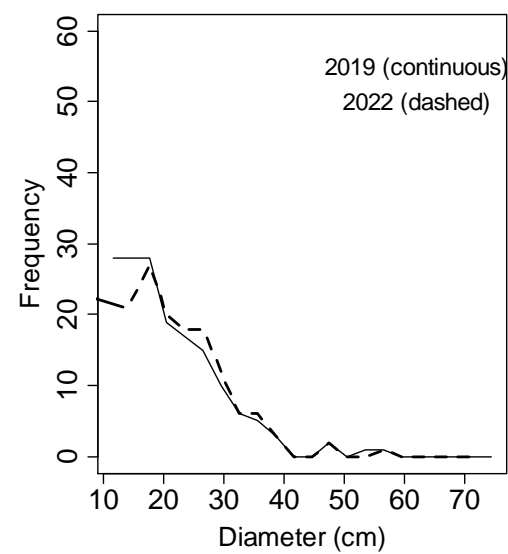

Figura 4. Prognose das distribuições diamétricas das espécies O. nutans (a), N. lanceolata (b) e O. bicolor (c) do remanescente de Floresta Ombrófila Mista.

Figure 4. Diameter distributions prognosis of O. nutans (a), N. lanceolata (b) and O. bicolor (c) species of the Mixed Ombrophilous Forest remnant.

$N$. lanceolata and $O$. bicolor species presented different behavior from the others. For $N$. lanceolata, which was also characterized by the high movement between diameter classes and presented the highest diameter increase among the species projected by transition matrix, it was estimated an increase of $3.33 \%$ of the population for 2019 in relation to 2016, however, a decrease of $0.72 \%$ for 2022. For O. bicolor, an increase of $2.53 \%$ was also estimated for 2019 and a decrease of $0.63 \%$ for 2022 .

\section{DISCUSSION}

Some studies have presented results of horizontal structure similar to the present study (HERRERA et al., 2009; CUBAS et al., 2016), which described the Lauraceae is one of the main families in terms of richness of tree species in MOF. In this sense, Canalez et al. (2006), when evaluating the dynamics of Lauraceae family structure between 1995 and 2004, concluded that it represented approximately $25 \%$ of the value of importance. Therefore, it is understood that the relationship between family and structure of the forest remnant is representative of the typology.

The high number of tree and the homogeneous distribution of $O$. puberula species in the fragment indicates a high potential for regeneration. In addition to found in intermediate and advanced stages of secondary succession (MARCUZZO et al., 2013), the species is also observed in the three most important phytophysiognomies in southern Brazil, such as MOF, Dense Ombrophilous Forest and Deciduous Seasonal Forest, which highlights its phenotypic plasticity and places it as one of the most common secondary species in the region (MCROBERTS et al., 2014).

The recruitment and mortality rates (Table 1), as well as the decreasing diameter distribution, suggest that the populations that make up the community under study are stable and self-regenerating, indicating that there is a balance between mortality and recruitment in the forest remnant (PICARD; GASPAROTTO, 2016). However, when evaluated separately, due to the different growth rates between species and their respective ecological characteristics, there was variation in the behavior of diameter distributions.

The increase in the number of Lauraceae family trees in the evaluated period (Table 1) is probably related to the successional advance and the reduction of gaps in the forest remnant. This tends to favor the development of secondary and climatic species with late behavior, as well as an increase in mortality of early secondary species (EBLING et al., 2013).

The pioneer and secondary species in the initial succession phase, such the $O$. puberula which presented the highest observed mortality, are distinguished from others with similar physical and genetic characteristics, due to the inability to develop in the understory, as a result of their ecophysiological characteristics of intolerance to shading (WHITMORE, 1989). On the other hand, there is a tendency to increase the number of trees of species such as $C$. sellowianum, indicating a behavior opposite to $O$. puberula. Therefore, the complex behavior of the remaining dynamics is a result of specific ecological characteristics of each species. 
When analyzing a MOF remnant in a secondary stage in Paraná State, Schaaf et al. (2005) observed the Lauraceae family presented species with highest growth in $d$. Thus, in comparison with the present study, the results may indicate that the species of this family present better development in more advanced stages. It is possible to highlight the future potential of the Lauraceae family influence on the forest remnant dynamics, especially with regard to the increase in $d$ and recruitment of new trees.

With values lower than those observed (Table 1), Péllico Netto et al. (2014) reported that, unlike the present study, $C$. glaziovii species showed the largest increase in $d$, followed by $N$. megapotamica and $O$. puberula. Therefore, the influence of other variables not addressed in the present study, intrinsic to the site and development of the population and species, may be the source of difference between increments of species.

It is important to note that $O$. nutans and O. puberula were isolated in the species grouping (Figure 2), indicating that they have different dynamics from the others. The first is probably characterized by the high number of recruiting trees, while the second by the high mortality in the same period (Table 1). The species in the group with $N$. lanceolata, $N$. megapotamica and $O$. bicolor were characterized by the greatest similarity between their values of annual periodic increase in $d$.

Although the canonical correlation value is moderate and the weights are considered low (Table 2), which demonstrates the Lauraceae family does not have a great influence on the dynamics of the studied MOF remnant (ÁVILA et al. 2011), the hypothesis the Lauraceae family provides an essential subsidy for the constitution of Araucaria forests presented by Klein (1974) cannot be refuted in face of such results. This is due to the observation of factors, such as the rates of increase in $d$, recruitment, and mortality, as well as the projections of species diameter distribution, which lead us to believe that, in a probable scenario of advancement of ecological succession, future results may show an increase in the correlation weights, in the face of a presumed gain in the value of importance of Lauraceae family.

Other evidence that strengthens this hypothesis is based on the sampling performed by Klein (1974), which apparently covered a large part of MOF area in the Santa Catarina State, as well as areas with fragments in an advanced successional stage. As described by the aforementioned author, the canopy, classified as a Megafanerophyte stratum, covered trees from 30 to $45 \mathrm{~m}$ in height. When compared to the canopy of the studied fragment, largest trees reach a maximum height of $25 \mathrm{~m}$ (MACHADO et al., 2008).

Regarding the prognosis of diameter distribution, there was an increase in number of trees of Lauraceae family in 2019 and a decrease in 2022 (Figure 3b). Thus, such behavior can indicate the successional advance and high mortality of species belonging to the ecophysiological groups of pioneers and early secondaries. In addition, it is noteworthy the biggest estimation errors are distributed in the first diameter classes, mainly due to the input vectors. As they take information from two measurements, the projections consider only the current state of the forest remnant, with possible changes in dynamics not fully contemplated (VANCLAY, 1995; PODLASKI, 2008).

An important aspect observed in this study was the absence of some species of Lauraceae family with high economic wood value, such as Ocotea odorifera Vellozo. Rohwer and Ocotea porosa, some of the most explored species in the woody cycle in Paraná State (HIGUCHI et al., 2012). Although they present attractive fruits and are conducive to zoochoric dispersion, the absence of these species is probably related to the lack of matrices in areas close to the forest remnant, which highlights the vulnerability of the regeneration process of these species (PILATTI et al., 2011).

Thus, for conservation purposes, aiming at restoring the biodiversity of forest remnant to the natural levels of typology, or even for economic purposes, directing at the logging of these species, human action through forest enrichment can be a viable mitigation alternative (MONTAGNINI et al., 1997), since some mechanisms for sustaining the ecosystem were not respected, such as the maintenance of propagation sources of the exploited species.

\section{CONCLUSIONS}

- Lauraceae family had a moderate influence on the dynamics of MOF remnant, with its tree species distributed into five groups of singular characteristics in diameter increment, recruitment and mortality.

- There is a reduction in the Ocotea puberula population (pioneer species) and an increase in the number of trees with climax characteristics, indicating an advance in the ecological succession of the forest remnant. As a result, the Lauraceae family has an increasing tendency in terms of density and, consequently, an increase in its influence on the forest remnant dynamics. 


\section{REFERENCES}

ÁVILA, A. D.; ARAUJO, M. M.; LONGHI, S. J.; GASPARIN, E. Agrupamentos florísticos na regeneração natural em remanescente de Floresta Ombrófila Mista, RS, Brasil. Scientia Forestalis, Piracicaba, v. 39, n. 91, p. 331-342, 2011.

CALLEGARO, R. M.; LONGHI, S. J.; ANDRZEJEWSKI, C. Variações estruturais entre grupos florísticos de um remanescente de Floresta Ombrófila Mista Montana em Nova Prata - RS. Ciência Florestal, Santa Maria, v. 25, n. 2, p. 337-349, 2015.

CANALEZ, G. G.; DALlA CORTE, A. P.; SANQUETTA, C. R. Dinâmica da estrutura da comunidade de lauráceas no período 1995-2004 em uma floresta de araucária no sul do estado do Paraná, Brasil. Ciência Florestal, Santa Maria, v. 16, n. 4, p. 357-367, 2006.

CUBAS, R.; WATZLAWICK, L. F.; FIGUEIREDO FILHO, A. Incremento, ingresso, mortalidade em um remanescente de Floresta Ombrófila Mista em Três Barras-SC. Ciência Florestal, Santa Maria, v. 26, n. 3, p. 889-900, 2016.

EBLING, A. A.; PÉLLICO NETTO, S.; WATZLAWICK, L. F.; MIRANDA, R. O. V.; ABRÃO, S. F. Ecologia e projeção diamétrica de três grupos arbóreos em remanescente de Floresta Ombrófila Mista em São Francisco de Paula, RS. Floresta, Curitiba, v. 43, n. 2, p. 261-270, 2013.

FIGUEIREDO FILHO, A.; DIAS, A. N.; STEPKA, T. F.; SAWCZUK, A. R. Crescimento, mortalidade, ingresso e distribuição diamétrica em Floresta Ombrófila Mista. Floresta, v. 40, n. 4, p. 763-776, 2010.

FONTANA, C.; GASPER, A. L.; SEVEGNANI, L. A raridade das espécies arbóreas de Lauraceae no planalto do Estado de Santa Catarina, Brasil. Hoehnea, São Paulo, v. 43, n. 3, p. 361-369, 2016.

HERRERA, H. A. R.; ROSOT, N. C.; ROSOT, M. A. D.; OLIVEIRA, Y. M. M. Análise florística e fitossociológica do componente arbóreo da Floresta Ombrófila Mista presente na reserva florestal Embrapa/Epagri, Caçador, SC-Brasil. Floresta, Curitiba, v. 39, n. 3, p. 485-500, 2009.

HIGUCHI, P.; SILVA, A. C.; SOUZA, T. F.; SOUZA, S. T.; GOMES, J. P.; SILVA, K. M.; SANTOS, K. F.; LINKE, C.; PAULINO, P. S. Influência de variáveis ambientais sobre o padrão estrutural e florístico do componente arbóreo, em um fragmento de Floresta Ombrófila Mista Montana em Lages, SC. Ciência Florestal, Santa Maria, v. 22, n. 1, p. 79-90, 2012.

KLEIN, R. M. O aspecto dinâmico do pinheiro brasileiro. Sellowia, Itajaí, v. 12, n. 12, p. 17-44, 1960.

KLEIN, R. M. Importância e fidelidade das Lauráceas na" formação de Araucária" do Estado de Santa Catarina. INSULA Revista de Botânica, v. 7, p. 3-19, 1974.

MACHADO, S.; NASCIMENTO, R. G. M.; AUGUSTYNCZIK, A. L. D.; SILVA, L. C. R.; FIGURA, M. A.; PEREIRA, E. M.; TÉO, S. J. Comportamento da relação hipsométrica de Araucaria angustifolia no capão da Engenharia Florestal da UFPR. Pesquisa Florestal Brasileira, Colombo, n. 56, p. 5-16, 2008.

MARCUZZO, S. B.; ARAÚJO, M. M.; LONGHI, S. J. Estrutura e relações ambientais de grupos florísticos em fragmento de Floresta Estacional Subtropical. Revista Árvore, Viçosa, v. 37, n. 2, p. 275-287, 2013.

MCROBERTS, R. E.; MOSER, P.; OLIVEIRA, L. Z.; VIBRANS, A. C. A general method for assessing the effects of uncertainty in individual-tree volume model predictions on large-area volume estimates with a subtropical forest illustration. Canadian Journal of Forest Research, Ottawa, v. 45, n. 1, p. 44-51, 2014.

MONTAGNINI, F.; EIBL, B.; GRANCE, L.; MAIOCCO, D.; NOZZI, D. Enrichment planting in overexploited subtropical forests of the Paranaense region of Misiones, Argentina. Forest Ecology and Management, Amsterdam, v. 99, n. 1-2, p. 237-246, 1997.

PÉLLICO NETTO, S.; EBLING, Â. A.; ARAÚJO, E. J. G. Growth stratification applied to prognosis of diametric structure in Araucaria Forest. Journal of Applied Mathematics and Physics, Wuhan, v. 2, n. 8, p. 753-761, 2014.

PICARD, N.; GASPAROTTO, D. Liocourt's law for tree diameter distribution in forest stands. Annals of Forest Science, Nancy, v. 73, n. 3, p. 751-755, 2016.

PILATTI, F. K.; AGUIAR, T.; SIMÕES, T.; BENSON, E. E.; VIANA, A. M. In vitro and cryogenic preservation of plant biodiversity in Brazil. In Vitro Cellular \& Developmental Biology-Plant, Raleigh, v. 47, n. 1, p. 82-

FLORESTA, Curitiba, PR, v. 51, n. 1, p. 164-173, jan/mar 2021.

Kieras, W. S. et.al.

ISSN eletrônico 1982-4688

DOI: $10.5380 /$ rf.v51 i1. 67629 
98, 2011.

PODLASKI, R. Characterization of diameter distribution data in near-natural forests using the BirnbaumSaunders distribution. Canadian Journal of Forest Research, Ottawa, v. 38, n. 3, p. 518-527, 2008.

REIS, M. S.; MONTAGNA, T.; MATTOS, A. G.; FILIPPON, S.; LADIO, A. H.; MARQUES, A. D. C.; ZECHINI, A. A.; PERONI, N.; MANTOVANI, A. Domesticated landscapes in Araucaria Forests, Southern Brazil: a multispecies local conservation-by-use system. Frontiers in Ecology and Evolution, Lausanne, v. 6, p. 11,2018

RIBEIRO, M. C.; METZGER, J. P.; MARTENSEN, A. C.; PONZONI, F. J.; HIROTA, M. M. The Brazilian Atlantic Forest: How much is left, and how is the remaining forest distributed? Implications for conservation. Biological Conservation, Montpellier, v. 142, n. 6, p. 1141-1153, 2009.

SCHAAF, L. B.; FIGUEIREDO FILHO, A.; SANQUETTA, C. R.; GALVÃO, F. Incremento diamétrico e em área basal no período 1979-2000 de espécies arbóreas de uma floresta ombrófila mista localizada no sul do Paraná. Floresta, Curitiba, v. 35, n. 2, p. 271-290, 2005.

VANCLAY, J. K. Growth models for tropical forests: a synthesis of models and methods. Forest Science, Bethesda, v. 41, n. 1, p. 7-42, 1995.

WHITMORE, T. C. Canopy gaps and the two major groups of forest trees. Ecology, Washington, v. 70, n. 3, p. 536-538, 1989. 